\title{
A Systematic Review of the Trace Element Concentrations in the Prostate Fluid of Normal Gland
}

\author{
Vladimir Zaichick ${ }^{1 *}$ and Sofia Zaichick ${ }^{2}$ \\ ${ }^{1}$ Department of Radionuclide Diagnostics, Medical Radiological Research Centre, Russia \\ ${ }^{2}$ Feinberg School of Medicine, Northwestern University, USA
}

*Corresponding author: Vladimir Zaichick, Department of Radionuclide Diagnostics, Medical Radiological Research Centre, Korolyev St. 4, Obninsk 249036, Kaluga region, Russia.

To Cite This Article: Vladimir Zaichick, A Systematic Review of the Trace Element Concentrations in the Prostate Fluid of Normal Gland. Am J Biomed Sci \& Res. 2020 - 6(6). AJBSR.MS.ID.001093. DOI: 10.34297/AJBSR.2020.06.001093.

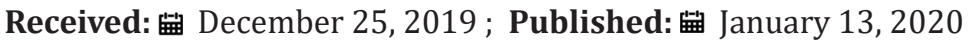

\begin{abstract}
Background: The prostate gland is subject to various disorders. The etiology and pathogenesis of these diseases are not well understood. Moreover, despite technological advancements, the differential diagnostics of prostate disorders has become progressively more complex and controversial. It was suggested that the measurement of Trace Elements (TEs) levels in Expressed Prostatic Fluid (EPF) may be useful as a biomarker. This suggestion promoted more detailed studies of the TEs concentrations in the EPF of healthy subjects.
\end{abstract}

Objective: The present study evaluated by systematic analysis the published data for concentration of TEs analyzed in EPF of normal gland.

Methods: The present systematic analysis included 1885 studies, all of which were published in the years from 1942 to 2019 and selected by searching the databases Scopus, PubMed, MEDLINE, ELSEVIER-EMBASE, Cochrane Library, and the Web of Science. The articles were analyzed and "Median of Means" and "Range of Means" were used to examine heterogeneity of TE concentrations in EPF of apparently healthy men. The objective analysis was performed on data from the 26 studies, with about 900 subjects.

Results: The median of concentration means for such TEs as Bromine (Br), Cadmium (Cd), Coper (Cu), Iron (Fe), Rubidium (Rb), Strontium (Sr), and Zinc (Zn) in EPF of apparently healthy men were (mg/L): Br-2.86, Cd-0.146, Cu-0.416, Fe-8.3, Rb-1.13, Sr-1.22, and Zn-501.

Conclusion: The study has demonstrated that the human prostatic secretion is a target fluid of human body for $\mathrm{Cd}, \mathrm{Fe}, \mathrm{Sr}$, and $\mathrm{Zn}$. Because of small sample size and high data heterogeneity, we recommend other primary studies.

Keywords: Prostate; Prostatic fluid; Biomarkers; Trace elements; Bromine; Cadmium; Coper; Iron; Rubidium; Strontium; Zinc

Abbreviations : PSA: Prostate-specific antigen; Zn : Zinc; Rb: Rubidium; TE: Trace Element; EPF : Expressed Prostatic Fluid; Cd : Cadmium; Cu : Coper; Fe : Iron; Sr : Strontium; FES : Flame Emission Spectrophotometry; AAS : Atomic Absorption Spectrophotometry; EDXRF : Energy Dispersive X-ray Fluorescent Microanalysis

\section{Introduction}

The prostate gland is subject to various disorders and of them chronic prostatitis, benign prostatic hyperplasia, and prostate cancer are the extremely common diseases of ageing men [13]. The etiology and pathogenesis of these diseases are not well understood. Moreover, despite technological advancements, the differential diagnostics of prostate disorders has become progressively more complex and controversial. This is particularly concerned with prostate cancer where the limitations and potential harms associated with the use of Prostate-Specific Antigen (PSA) as a diagnostic marker. The situation stimulates significant investigation of numerous novel biomarkers that demonstrate varying capacities to detect prostate cancer and can decrease unnecessary biopsies [4].

In our previous studies the significant involvement of Zinc (Zn), Rubidium (Rb) and some other Trace Elements (TEs) in the normal physiology of the prostate was found [5-30]. It was also found a great deformation of TE concentrations in affected prostate and was demonstrated that the changes of some TEs content, as well 
as levels of some TE ratios in the prostate tissue can be used as the biomarkers of prostate diseases [31-41] and global environmental contamination [42]. Moreover, it was shown that levels of some TEs in prostate tissue play a very important role in carcinogenesis of the gland [43-45].

One of the main functions of the prostate gland is the production of prostatic fluid [46]. It contains a high concentration of $\mathrm{Rb}, \mathrm{Zn}$ and some other TEs, in comparison with levels in blood serum and other human body fluids. The first finding of remarkably high levels of $\mathrm{Zn}$ in human Expressed Prostatic Fluid (EPF) was reported in the early 1960s [47]. After analyzing EPF expressed from the prostates of 8 apparently healthy men, aged 25-55 years, it was found that $\mathrm{Zn}$ concentrations varied from 300 to $730 \mathrm{mg} / \mathrm{L}$. After this finding several investigators suggested that the measurement of $\mathrm{Zn}$ levels in EPF may be useful as a marker of abnormal prostate secretory function $[48,49]$. This suggestion promoted more detailed studies of the TEs concentrations in the EPF of healthy subjects and in those with different prostatic diseases, including prostate cancer [49-70].

TEs are vital for the normal functioning of the human body [71]. For example, $\mathrm{Zn}$ is an essential nutritional TE, especially in terms of proteins and nucleic acids metabolism. It is required for the catalytic activity of at least 300 enzymes, and is involved in the human immune system, in tissue repair, and in DNA syntheses. There are a lot of data on the subject. However, the exact role of $\mathrm{Zn}$ and other TEs in normal and pathophysiology of the prostate is until now unknown. Several studies have reported the TEs contents in EPF of normal and affected gland [47-56,72-85]. However, further investigation has been considered necessary to provide clearer hypothesis about the role of TEs in etiology and pathogenesis of prostate disorders, because the findings of various studies indicate some discrepancies.

The present study addresses the significance of prostatic fluid TEs levels as biomarker. Therefore, we systematically reviewed the available literature and performed a statistical analysis of TEs concentrations in EPF of normal gland, which may shed valuable insight into the etiology and diagnosis of prostate disorders.

\section{Materials and Methods}

\section{Data sources and search strategy}

Aiming at finding the most relevant articles for this review, a thorough comprehensive web search was conducted from Scopus, PubMed, MEDLINE, ELSEVIER-EMBASE, Cochrane Library, and the Web of Science databases between 1942 to November 2019, using the key words: trace element concentration, expressed prostatic fluid, and their combination. For example, the search terms for such TE concentration as Zn were: 'zinc concentration', 'Zn concentration', 'zinc content', 'Zn content', 'zinc level', 'Zn level' 'prostatic fluid zinc, 'prostatic fluid Zn, 'zinc of expressed prostatic fluid', and 'Zn of expressed prostatic fluid'. The language was not restricted. The titles from the search results were evaluated closely and determined to be acceptable for potential inclusion criteria. Also, references from the selected articles were examined as further search tools. Relevant studies noted in the reference lists of each selected article were also evaluated for inclusion.

\section{Eligibility criteria}

Studies were included if the control groups were healthy human males with no history or evidence of andrologia or urologic disease and TEs were detected in samples of EPF. Studies were excluded if they were case reports or reviews. Studies involving subjects that were using $\mathrm{Zn}$ and other TEs supplementation were also excluded.

\section{Data extraction}

A standard extraction of data was applied, and the following available variables were extracted from each paper: method of TEs determination, number and age of health persons, samples preparing, mean and median of TEs concentrations, standard deviations of mean, and range of TEs concentrations.

\section{Statistical analysis}

Studies were combined based on means of TEs concentrations in EPF. The articles were analyzed and "Median of Means" and "Range of Means" were used to examine heterogeneity of TEs concentrations. The objective analysis was performed on data from the 29 studies, with about 900 healthy subjects.

\section{Results}

\begin{tabular}{|c|c|c|c|c|c|c|}
\hline Element & Reference & Meth. & $\mathbf{n}$ & Age & $\mathrm{M} \pm \mathrm{SD}$ & Range* \\
\hline \multirow{6}{*}{$\mathrm{Br}$} & Zaichick et al. (2016) [52] & EDXRF & 51 & $18-82$ & $3.58 \pm 3.31$ & $0.16-10.0$ \\
\hline & \multirow{2}{*}{ Zaichic Zaichick (2018) [53] } & \multirow{2}{*}{ EDXRF } & 13 & $18-40$ & 6.35 & - \\
\hline & & & 38 & $41-82$ & 2.86 & - \\
\hline & Zaichick Zaichick (2018) [54] & EDXRF & 42 & $31-75$ & $2.81 \pm 2.88$ & $0.490-8.53$ \\
\hline & Zaichick Zaichick (2018) [55] & EDXRF & 38 & $41-82$ & $2.86 \pm 2.93$ & $0.490-8.53$ \\
\hline & Zaichick Zaichick (2018) [56] & EDXRF & 38 & $41-82$ & $2.86 \pm 2.93$ & $0.490-8.53$ \\
\hline $\mathrm{Cd}$ & Mo et al. (2000) [83] & ICP-AES & 25 & $57.4 \pm 6.8$ & 0.146 & $0.120-0.176$ \\
\hline $\mathrm{Cu}$ & Mo et al. (2000) [83] & ICP-AES & 25 & $57.4 \pm 6.8$ & 0.416 & $0.354-0.473$ \\
\hline
\end{tabular}




\begin{tabular}{|c|c|c|c|c|c|c|}
\hline \multirow{6}{*}{$\mathrm{Fe}$} & Zaichick et al. (2016) [52] & EDXRF & 51 & $18-82$ & $9.04 \pm 7.28$ & $1.27-39.8$ \\
\hline & \multirow{2}{*}{ Zaichick Zaichick (2018) [53] } & \multirow{2}{*}{ EDXRF } & 13 & $18-40$ & 12.1 & - \\
\hline & & & 38 & $41-82$ & 8.29 & - \\
\hline & Zaichick Zaichick (2018) [54] & EDXRF & 42 & $31-75$ & $8.29 \pm 7.49$ & $1.27-39.8$ \\
\hline & Zaichick Zaichick (2018) [55] & EDXRF & 38 & $41-82$ & $8.30 \pm 7.62$ & $1.27-39.8$ \\
\hline & Zaichick Zaichick (2018) [56] & EDXRF & 38 & $41-82$ & $8.30 \pm 7.62$ & $1.27-39.8$ \\
\hline \multirow{7}{*}{$\mathrm{Rb}$} & Zaichick et al. (1981) [49] & EDXRF & 15 & - & $1.11 \pm 0.57$ & - \\
\hline & Zaichick et al. (2016) [52] & EDXRF & 51 & $18-82$ & $1.10 \pm 0.51$ & $0.38-2.45$ \\
\hline & \multirow{2}{*}{ Zaichick Zaichick (2018) [53] } & \multirow{2}{*}{ EDXRF } & 13 & $18-40$ & 0.91 & - \\
\hline & & & 38 & $41-82$ & 1.16 & - \\
\hline & Zaichick Zaichick (2018) [54] & EDXRF & 42 & $31-75$ & $1.15 \pm 0.51$ & $0.376-2.45$ \\
\hline & Zaichick Zaichick (2018) [55] & EDXRF & 38 & $41-82$ & $1.16 \pm 0.52$ & $0.376-2.45$ \\
\hline & Zaichick Zaichick (2018) [56] & EDXRF & 38 & $41-82$ & $1.16 \pm 0.52$ & $0.376-2.45$ \\
\hline \multirow{6}{*}{$\mathrm{Sr}$} & Zaichick et al. (2016) [52] & EDXRF & 51 & $18-82$ & $\leq 0.76$ & - \\
\hline & \multirow{2}{*}{ Zaichick Zaichick (2018) [53] } & \multirow{2}{*}{ EDXRF } & 13 & $18-40$ & 0.87 & - \\
\hline & & & 38 & $41-82$ & 1.27 & - \\
\hline & Zaichick Zaichick (2018) [54] & EDXRF & 42 & $31-75$ & $1.17 \pm 0.83$ & $040-3.44$ \\
\hline & Zaichick Zaichick (2018) [55] & EDXRF & 38 & $41-82$ & $1.27 \pm 0.84$ & $040-3.44$ \\
\hline & Zaichick Zaichick (2018) [56] & EDXRF & 38 & $41-82$ & $1.27 \pm 0.84$ & $040-3.44$ \\
\hline \multirow{27}{*}{$\mathrm{Zn}$} & Birnbaum et al. (1961) [72] & $\mathrm{XRF}$ & - & - & 490 & - \\
\hline & Mackenzie et al. (1962) [47] & XRF & 8 & $37(25-55)$ & $490 \pm 130$ & $265-666$ \\
\hline & Burgos (1974) [73] & - & - & - & 47.1 & - \\
\hline & Marmar et al. (1975) [74] & AAS & 33 & - & $451 \pm 215$ & - \\
\hline & Anderson Fair (1976) [75] & AAS & 15 & $50(30-74)$ & $352 \pm 190$ & - \\
\hline & Fair et al. (1976) [76] & AAS & 49 & $52(24-76)$ & $455 \pm 208$ & $150-1000$ \\
\hline & Paz et al. (1977) [77] & AAS & 53 & - & $299 \pm 202$ & - \\
\hline & Fair Cordonnier (1978) [78] & AAS & 63 & $52(24-76)$ & $455 \pm 208$ & - \\
\hline & Homonnai et al. (1978) [79] & AAS & 12 & - & $335 \pm 45$ & - \\
\hline & Marmar et al. (1980) [48] & AAS & 33 & - & $451 \pm 215$ & - \\
\hline & Zaichick et al. (1981) [49] & EDXRF & 15 & - & $580 \pm 183$ & - \\
\hline & Zaneveld Tauber (1981) [80] & - & - & - & 50.3 & - \\
\hline & Kavanagh et al. (1982) [81] & AAS & 35 & 49.2 & 580 & - \\
\hline & Kavanagh (1983) [82] & AAS & 152 & - & $595 \pm 222$ & $52-1308$ \\
\hline & Zaichick et al. (1996) [50] & EDXRF & 22 & $49(22-75)$ & $590 \pm 210$ & 291-1118 \\
\hline & Mo et al. (2000) [83] & ICPAES & 25 & $57.4 \pm 6.8$ & 305 & 243-379 \\
\hline & Cai et al. (2002) [84] & AAS & 22 & - & $220 \pm 85$ & - \\
\hline & Gómez et al. (2007) [85] & AAS & 10 & $44(40-62)$ & $519 \pm 374$ & $131-1242$ \\
\hline & Costello Franklin (2009) [51] & EDXRF & 24 & - & 588 & - \\
\hline & Zhuang et al. (2009) * [84] & AAS & 20 & - & $802 \pm 39$ & - \\
\hline & He et al. $(2013)^{*}[84]$ & AAS & 40 & - & $825 \pm 71$ & - \\
\hline & Zaichick et al. (2016) [52] & EDXRF & 51 & $18-82$ & $573 \pm 202$ & 253-048 \\
\hline & \multirow{2}{*}{ Zaichick Zaichick (2018) [53] } & \multirow{2}{*}{ EDXRF } & 13 & $28(18-40)$ & $501 \pm 47$ & \\
\hline & & & 38 & $59(41-82)$ & $598 \pm 34$ & - \\
\hline & Zaichick Zaichick (2018) [54] & EDXRF & 42 & $31-75$ & $559 \pm 204$ & $253-948$ \\
\hline & Zaichick Zaichick (2018) [55] & EDXRF & 38 & $41-82$ & $598 \pm 207$ & $253-948$ \\
\hline & Zaichick Zaichick (2018) [56] & EDXRF & 38 & $41-82$ & $598 \pm 207$ & $253-948$ \\
\hline
\end{tabular}

Note: M-Arithmetic Mean, SD-Standard Deviation of Mean, EDXRF-Energy Dispersive X-Ray Fluorescence, ICPAES - Inductively Coupled Plasma Atomic Emission Spectrometry, XRF-X-Ray Fluorescence, AAS-Atomic Absorption Spectrophotometry. ${ }^{*}$ ata of Chinese researches taken from the review Cui, et al. (2015) [84]. 
A total of 1885 unduplicated studies were identified. Among them 26 studies were ultimately selected according to eligibility criteria, that investigated Bromine (Br), Cadmium (Cd), Coper $(\mathrm{Cu})$, Iron (Fe), Rb, Strontium ( $\mathrm{Sr}$ ), and Zn concentrations in EPF of normal prostate (Table 1). Table 1 summarizes general data from the 26 studies. The retrieved studies involved about 900 apparently healthy subjects. The ages of subjects were available for 12 studies and ranged from 18-82 years. The information about analytical method was available for 24 studies.

Fife studies determined $\mathrm{Br}, \mathrm{Fe}$, and $\mathrm{Sr}$ concentration in EPF using energy dispersive X-ray fluorescence analysis (EDXRF) [5256]. One study investigated $\mathrm{Cd}$ and $\mathrm{Cu}$ levels in EPF by inductively coupled plasma atomic emission spectrometry (ICP-AES) [83]. Method EDXRF was used in six studies for the measurement of prostatic fluid $\mathrm{Rb}$ contents [49,52-56]. Concentration of $\mathrm{Zn}$ in EPF was determined in all 26 selected studies [47-56,72-85]. Fourteen studies determined $\mathrm{Zn}$ concentration by the destructive analytical methods: thirteen using Atomic Absorption Spectrophotometry (AAS) and one using ICPAES. Ten studies detected $\mathrm{Zn}$ concentration in EPF by the nondestructive analytical methods, such as X-ray Fluorescence Analysis (XRF, 2 studies) and EDXRF (8 studies).

Table 2 depicts the median and range of means of the $\mathrm{Br}, \mathrm{Cd}, \mathrm{Cu}$, $\mathrm{Fe}, \mathrm{Rb}, \mathrm{Sr}$, and $\mathrm{Zn}$ concentrations in normal human prostatic fluid founded in our review. Table 3 \& 4 present data of $\mathrm{Zn}$ concentration in EPF of normal human prostates obtained by the destructive (AAS and ICP-AES) and nondestructive (XRF and EDXRF) analytical methods, respectively. Table 5 presents the differences between the mean of $\mathrm{Br}, \mathrm{Cd}, \mathrm{Cu}, \mathrm{Fe}, \mathrm{Rb}, \mathrm{Sr}$, and $\mathrm{Zn}$ concentration in the prostatic fluid obtained by our review and the mean of these elements in blood serum, urine, breast milk, and mixed saliva of Reference Man

\begin{tabular}{|c|c|c|c|c|}
\hline Element & Number of References & Median of means mg/L & Range of means $\left(M_{\min }-M_{\max }\right), \mathrm{mg} / \mathrm{L}$ & Ratio $\mathbf{M}_{\max } / \mathbf{M}_{\min }$ \\
\hline $\mathrm{Br}$ & 5 & 2.86 & $2.81-6.35$ & 2.26 \\
\hline $\mathrm{Cd}$ & 1 & 0.146 & - & - \\
\hline $\mathrm{Cu}$ & 1 & 0.416 & - & - \\
\hline $\mathrm{Fe}$ & 5 & 8.3 & $8.29-12.1$ & 1.44 \\
\hline $\mathrm{Rb}$ & 6 & 1.13 & 0,91-1.16 & 1.27 \\
\hline $\mathrm{Sr}$ & 5 & 1.22 & $\leq 0.76-1.27$ & $>1.67$ \\
\hline $\mathrm{Zn}$ & 25 & 501 & $47.1-825$ & 17.5 \\
\hline
\end{tabular}

\begin{tabular}{|c|c|c|c|c|}
\hline Reference & Method & $\mathbf{n}$ & Age, years M(Range) & $\mathrm{Zn}, \mathrm{mg} / \mathrm{L} \mathrm{M} \pm \mathrm{SD}$ \\
\hline Marmar, et al. (1975) [74] & AAS & 33 & - & $451 \pm 215$ \\
\hline Anderson, Fair (1976) [75] & AAS & 15 & $50(30-74)$ & $352 \pm 190$ \\
\hline Fair, et al. (1976) [76] & AAS & 49 & $52(24-76)$ & $455 \pm 208$ \\
\hline Paz, et al. (1977) [77] & AAS & 53 & - & $299 \pm 202$ \\
\hline Fair, Cordonnier (1978) [78] & AAS & 63 & $52(24-76)$ & $455 \pm 208$ \\
\hline Homonnai, et al. (1978) [79] & AAS & 12 & - & $335 \pm 45$ \\
\hline Marmar, et al. (1980) [48] & AAS & 33 & - & $451 \pm 215$ \\
\hline Kavanagh, et al. (1982) [81] & AAS & 35 & 49.2 & 580 \\
\hline Kavanagh (1983) [82] & AAS & 152 & - & $595 \pm 222$ \\
\hline Mo, et al. (2000) [83] & ICPAES & 25 & $57.4 \pm 6.8$ & 305 \\
\hline Cai, et al. (2002) [84] & AAS & 22 & - & $220 \pm 85$ \\
\hline Gómez, et al. (2007) [85] & AAS & 10 & $44(40-62)$ & $519 \pm 374$ \\
\hline Zhuang, et al. (2009) * [84] & AAS & 20 & - & $802 \pm 39$ \\
\hline He, et al. (2013)*[84] & AAS & 40 & - & $825 \pm 71$ \\
\hline Median of means, mg/L & \multicolumn{4}{|c|}{453} \\
\hline Range of means $\left(\mathrm{M}_{\min }-\mathrm{M}_{\max }\right), \mathrm{mg} / \mathrm{L}$ & \multicolumn{4}{|c|}{$220-825$} \\
\hline Ratio $\mathrm{M}_{\max } / \mathrm{M}_{\min }$ & \multicolumn{4}{|c|}{$(825 / 220)=3.75$} \\
\hline
\end{tabular}

Note: M-Arithmetic Mean, SD-Standard Deviation of Mean, AAS-Atomic Absorption Spectrophotometry, ICPAES- Inductively Coupled Plasma Atomic Emission Spectrometry.

*Data of Chinese researches taken from the review Cui, et al. (2015) [84]. 


\begin{tabular}{|c|c|c|c|c|}
\hline Reference & Method & $\mathbf{n}$ & Age, years M(Range) & $\mathrm{Zn}, \mathrm{mg} / \mathrm{L} \mathrm{M} \pm \mathrm{SD}$ \\
\hline Birnbaum, et al. (1961) [72] & XRF & - & - & 490 \\
\hline Mackenzie, et al. (1962) [47] & XRF & 8 & $37(25-55)$ & $490 \pm 130$ \\
\hline Zaichick, et al. (1981) [49] & EDXRF & 15 & - & $580 \pm 183$ \\
\hline Zaichick, et al. (1996) [50] & EDXRF & 22 & $49(22-75)$ & $590 \pm 210$ \\
\hline Costello, Franklin (2009) [86] & EDXRF & 24 & - & 588 \\
\hline Zaichick, et al. (2016) [52] & EDXRF & 51 & $18-82$ & $573 \pm 202$ \\
\hline Zaichick, Zaichick (2018) [53] & EDXRF & 13 & $28(18-40)$ & $501 \pm 47$ \\
\hline & & 38 & $59(41-82)$ & $598 \pm 34$ \\
\hline Zaichick, Zaichick (2018) [54] & EDXRF & 42 & $31-75$ & $559 \pm 204$ \\
\hline Zaichick, Zaichick (2018) [55] & EDXRF & 38 & $41-82$ & $598 \pm 207$ \\
\hline Zaichick, Zaichick (2018) [56] & EDXRF & 38 & $41-82$ & $598 \pm 207$ \\
\hline Median of means, mg/L & \multicolumn{4}{|c|}{584} \\
\hline Range of means $\left(M_{\min }-M_{\max }\right), \mathrm{mg} / \mathrm{L}$ & \multicolumn{4}{|c|}{$490-598$} \\
\hline Ratio $\mathrm{M}_{\max } / \mathrm{M}_{\min }$ & \multicolumn{4}{|c|}{$(598 / 490)=1.22$} \\
\hline
\end{tabular}

Note: M-Arithmetic Mean, SD-Standard Deviation of Mean, XRF-X-Ray Fluorescence, EDXRF-Energy Dispersive X-Ray Fluorescence.

Table 5: The differences between the mean of $\mathrm{Br}, \mathrm{Cd}, \mathrm{Cu}, \mathrm{Fe}, \mathrm{Rb}, \mathrm{Sr}$, and $\mathrm{Zn}$ concentration in the prostatic fluid and in blood serum, urine, breast milk, and mixed saliva of Reference Man (mg/L).

\begin{tabular}{|c|c|c|c|c|c|c|c|c|c|}
\hline \multirow{3}{*}{ Element } & \multirow{3}{*}{$\begin{array}{c}\text { This work } \\
\text { Prostatic fluid } \\
1\end{array}$} & \multicolumn{4}{|c|}{ Reference Man [90-92] } & \multicolumn{4}{|c|}{ Ratios } \\
\hline & & Blood serum & Urine & Breast milk & Mixed saliva & \multirow{2}{*}{$1 / 2$} & \multirow{2}{*}{$1 / 3$} & \multirow{2}{*}{$1 / 4$} & \multirow{2}{*}{$1 / 5$} \\
\hline & & 2 & 3 & 4 & 5 & & & & \\
\hline $\mathrm{Br}$ & 2.86 & 4.5 & 6 & 2.5 & 1.5 & 0.64 & 0.48 & 1.14 & 1.91 \\
\hline $\mathrm{Cd}$ & 0.146 & 0.0002 & 0.003 & $<0.001$ & - & 730 & 48.7 & $>146$ & - \\
\hline $\mathrm{Cu}$ & 0.416 & 0.95 & 0.045 & 0.3 & 0.08 & 0.44 & 9.24 & 1.39 & 5.2 \\
\hline $\mathrm{Fe}$ & 8.3 & 1 & 0.15 & 0.45 & 0.61 & 8.3 & 55.3 & 18.4 & 13.6 \\
\hline $\mathrm{Rb}$ & 1.13 & 0.15 & 2.5 & 0.75 & 0.69 & 7.53 & 0.45 & 1.51 & 1.64 \\
\hline $\mathrm{Sr}$ & 1.22 & 0.02 & 0.17 & 0.02 & 0.18 & 61 & 7.18 & 61 & 6.78 \\
\hline $\mathrm{Zn}$ & 584 & 0.95 & 0.25 & 1.5 & 0.47 & 615 & 2336 & 389 & 1243 \\
\hline
\end{tabular}

\section{Discussion}

Samples of EPF are much more available for study than prostate tissue and can be obtained without damaging the prostate gland. Information about TEs concentrations in prostatic fluid in different prostatic diseases is of obvious interest, not only to more profoundly understand the etiology and pathogenesis of prostatic diseases, but also for their diagnosis, particularly for prostate cancer diagnostics. Thus, it dictates a need in reliable values for the TEs concentrations in the EPF of apparently healthy subjects ranging from young adult males to elderly persons. The range of means of $\mathrm{Br}$ concentration reported in the literature for normal EPF varies from $2.81 \mathrm{mg} / \mathrm{L}$ [54] to $6.15 \mathrm{mg} / \mathrm{L}$ [53] with median of means $2.81 \mathrm{mg} / \mathrm{L}$ (Table $1 \& 2$ ).

Because the $\mathrm{Cd}$ and $\mathrm{Cu}$ levels in EPF were investigated only in one study [83] it was impossible to calculate the median and range of means for these TEs. The means presented in this study for the $\mathrm{Ca}$ and $\mathrm{Cu}$ concentrations were $0.146 \mathrm{mg} / \mathrm{L}$ and $0.416 \mathrm{mg} / \mathrm{L}$, respectively. The range of means of $\mathrm{Fe}$ concentration reported in the literature for normal EPF varies from $8.29 \mathrm{mg} / \mathrm{L}$ [54] to $12.1 \mathrm{mg} / \mathrm{L}$ [53] with median of means $8.30 \mathrm{mg} / \mathrm{L}$ (Table $1 \& 2$ ). The range of means of $\mathrm{Rb}$ concentration reported in the literature for normal EPF varies from $0.91 \mathrm{mg} / \mathrm{L}$ [53] to $1.16 \mathrm{mg} / \mathrm{L}$ [55] with median of means $1.13 \mathrm{mg} / \mathrm{L}$ (Table $1 \& 2$ ). The range of means of $\mathrm{Sr}$ concentration reported in the literature for normal EPF varies from $\leq 0.76 \mathrm{mg} / \mathrm{L}$ [52] to $1.27 \mathrm{mg} / \mathrm{L}$ [56] with median of means $1.22 \mathrm{mg} / \mathrm{L}$ (Table 1\&2).

The narrow ranges of means of $\mathrm{Br}, \mathrm{Fe}, \mathrm{Rb}$, and $\mathrm{Sr}$ were demonstrated in the present review because all these elements were investigated only one group of researches. The other situation with the range of means was found for $\mathrm{Zn}$ concentration in EPF which was determined in 26 studies by different groups of researches. The range of means of $\mathrm{Zn}$ concentration reported in the literature for normal EPF varies widely from $47.1 \mathrm{mg} / \mathrm{L}$ [73] to $825 \mathrm{mg} / \mathrm{L}$ [84] with median of means $501 \mathrm{mg} / \mathrm{L}$ (Table $1 \& 2$ ). Other words maximal value of cited means of $\mathrm{Zn}$ concentrations 17.5 times higher 
minimal value of cited means (Table 2). As indicated above, the range of means of $\mathrm{Zn}$ concentration reported in the literature for normal EPF varies widely. This can be explained by a dependence of $\mathrm{Zn}$ content on many factors, including age, ethnicity, mass of the gland, and others. Not all these factors were strictly controlled in cited studies. However, published data allowed us to estimate the effect of age on $\mathrm{Zn}$ concentration in EPF of normal prostate.

In one study a significant increase in $\mathrm{Zn}$ concentration with increasing of age was shown by the Pearson's coefficient of correlation between age and $\mathrm{Zn}$ concentration in EPF [53]. According this study Zn concentration in EPF of apparently healthy men aged 41-82 years was about 20\% higher than in age from 18 to 40 years. But this finding does not agree with other published data. For example, in the first quantitative XRF analysis of $\mathrm{Zn}$ concentration in EPF of 8 apparently healthy men aged 25-55 years no significant variation with age was recognized, despite no statistical treatment of results was done in this investigation [47]. Fair and Cordonnier [78] did not find any changes in metal level with age using AAS for Zn measurement in EPF specimens obtained from 63 normal male subjects in age from 24 to 76 years. The conclusion was followed from the level of differences between the mean $\mathrm{Zn}$ results for three age groups evaluated by parametric Student's t-test.

Additionally, Zn, concentration in prostatic fluid showed no age relationship in the study of Kavanagh et al. [81] when 35 specimens obtained from normal male subjects in age from 15 to 85 years were measured by AAS and the Pearson correlation between age and $\mathrm{Zn}$ concentration was used. It is, therefore, reasonable to assume that Zn level in EPF do not change with age or, at least, slightly increase in age above 40 years. Another and, in our opinion, leading cause of inter-observer variability was insufficient quality control of results in these studies. In many reported papers such destructive analytical methods as AAS and ICP-AES were used. These methods need in sample acid digestion under high temperature. There is evidence that by use of this treatment some quantities of TEs, including Zn, are lost [86-88].

On the other hand, TEs of chemicals used for acid digestion can contaminate the EPF samples. Thus, when using destructive analytical methods, it is necessary to control for the losses of TEs, for complete acid digestion of the sample, and for the contaminations by TEs during sample decomposition, which needs adding some chemicals. It is possible to avoid these not easy procedures using non-destructive methods. Such method as XRF and, particularly, EDXRF is a fully instrumental and nondestructive analytical tool because a drop of EPF or other biological fluid is investigated without requiring any sample pretreatment or its consumption [52,89-91]. In present study, in 14 articles Zn concentration in EPF samples was determined by the destructive analytical methods (13 articles-AAS and 1 article-ICP-AES) and in 10 articles nondestructive analytical methods were used for this purpose ( 2 articles-XRF and 8 articles-EDXRF).
Thus, published data allowed us to estimate the effect of acid digestion at the results of $\mathrm{Zn}$ determination in EPF on normal prostates (Table 3\&4). In articles with destructive analytical methods the range of means for $\mathrm{Zn}$ concentration in EPF of normal prostates varied from $220 \mathrm{mg} / \mathrm{L}$ to $825 \mathrm{mg} / \mathrm{L}$ (ratio Mmax/ Mmin=3.75), with median of means $453 \mathrm{mg} / \mathrm{L}$ (Table 3). The articles with nondestructive analytical methods have the rather narrow range of means for $\mathrm{Zn}$ concentration in EPF of normal prostates from 490mg/L to 598mg/L (ratio Mmax/Mmin=1.22), with median of means $584 \mathrm{mg} / \mathrm{L}$. Thus, median of means for $\mathrm{Zn}$ concentration in EPF of normal prostates obtained by destructive analytical methods is $22 \%$ lower than that obtained by nondestructive methods. It is, therefore, reasonable to conclude that the choice of analytical method and quality control of results are very important factors for using the $\mathrm{Zn}$ and other TEs concentration in EPF as biomarker.

The obtained median of means for Cd concentrations in EPF of normal gland was two orders of magnitude higher than mean values of the metal content in blood serum and breast milk, and about 50 times higher than in urine. The median of means for $\mathrm{Fe}$ concentrations in normal human prostatic fluid was at least one order of magnitude higher than mean values of the metal content in urine, breast milk, and mixed saliva, and 8 times higher than in blood serum. The median of means for Sr concentrations in normal human prostatic fluid was 60 times higher than mean values of the metal content in blood serum and breast milk, and 7.2 and 6.8 times higher than in urine and mixed saliva, respectively. The median of means for $\mathrm{Zn}$ concentrations in normal human prostatic fluid was at least three orders of magnitude higher than mean values of the metal content in urine and mixed saliva, and two orders of magnitude higher than in blood serum and breast milk.

Thus, the comparison of obtained data with TEs concentrations in some fluids of Reference Man demonstrated that the human prostatic secretion is a target fluid of human body for $\mathrm{Cd}, \mathrm{Fe}, \mathrm{Sr}$, and $\mathrm{Zn}$. There is some limitation in our study, which need to be taken into consideration when interpreting the results of this review. The concentrations of only seven TEs including $\mathrm{Br}, \mathrm{Cd}, \mathrm{Cl}, \mathrm{Fe}, \mathrm{Rb}$, $\mathrm{Sr}$, and $\mathrm{Zn}$ were measured in EPF. The sample size of each study was relatively small, and a total of about 900 normal controls were investigated from all 26 studies. As such, it is hard to make definitive conclusions about the clinical value of the TEs concentration in EPF as biomarker.

\section{Conclusion}

The present study is a comprehensive study regarding the determination of $\mathrm{Br}, \mathrm{Cd}, \mathrm{Cl}, \mathrm{Fe}, \mathrm{Rb}, \mathrm{Sr}$, and $\mathrm{Zn}$ concentration in $\mathrm{EPF}$ as a biomarker for the diagnostics of prostate disorders. The study has demonstrated that the human prostatic secretion is a target fluid of human body for $\mathrm{Cd}, \mathrm{Fe}, \mathrm{Sr}$, and $\mathrm{Zn}$. Because of small sample size and high heterogeneity of data for $\mathrm{Zn}$, we recommend other primary studies. 


\section{Compliance with Ethical Standards}

\section{Conflicts of Interest}

The authors declare that they have no financial conflicts of interest.

\section{Ethical Statement}

There have been no human or animal experiments carried out for this article.

\section{References}

1. Nickel JC (2011) Prostatitis. Can Urol Assoc J 5(5): 306-315.

2. Lim KB (2017) Epidemiology of clinical benign prostatic hyperplasia Asian J Urol 4(3): 148-151.

3. Siegel RL, Miller KD, Jemal A (2017) Cancer statistics, 2017. CA Cancer J Clin 67(1): 7-30.

4. Sharma S, Zapatero-Rodríguez J, O’Kennedy R (2017) Prostate cancer diagnostics: Clinical challenges and the ongoing need for disruptive and effective diagnostic tools. Biotechnol Adv 35(2): 135-149.

5. Zaichick S, Zaichick V (2011) The Br, Fe, Rb, Sr, and Zn content and interrelation in intact and morphologic normal prostate tissue of adult men investigated by energy dispersive X-ray fluorescent analysis. X-Ray Spectr 40(6): 464-469.

6. Zaichick V (2004) INAA and EDXRF applications in the age dynamics assessment of $\mathrm{Zn}$ content and distribution in the normal human prostate. J Radioanal Nucl Chem 262(1): 229-234.

7. Zaichick S, Zaichick V (2011) INAA application in the age dynamics assessment of $\mathrm{Br}, \mathrm{Ca}, \mathrm{Cl}, \mathrm{K}, \mathrm{Mg}, \mathrm{Mn}$, and $\mathrm{Na}$ content in the normal human prostate. J Radioanal Nucl Chem 288(1): 197-202.

8. Zaichick S, Zaichick V (2011) The effect of age on Ag, Co, Cr, Fe, Hg, Sb, $\mathrm{Sc}, \mathrm{Se}$, and $\mathrm{Zn}$ contents in intact human prostate investigated by neutron activation analysis. Appl Radiat Isot 69(6): 827-833.

9. Zaichick V, Nosenko S, Moskvina I (2012) The effect of age on 12 chemical element contents in intact prostate of adult men investigated by inductively coupled plasma atomic emission spectrometry. Biol Trace Elem Res 147(1-3): 49-58.

10. Zaichick S, Zaichick V, Nosenko S, Moskvina I (2012) Mass fractions of 52 trace elements and zinc trace element content ratios in intact human prostates investigated by inductively coupled plasma mass spectrometry. Biol Trace Elem Res 149(2): 171-183.

11. Zaichick S, Zaichick V (2013) Relations of morphometric parameters to zinc content in paediatric and nonhyperplastic young adult prostate glands. Andrology 1(1): 139-146.

12. Zaichick V, Zaichick S (2013) The effect of age on $\mathrm{Br}, \mathrm{Ca}, \mathrm{Cl}, \mathrm{K}, \mathrm{Mg}, \mathrm{Mn}$, and $\mathrm{Na}$ mass fraction in pediatric and young adult prostate glands investigated by neutron activation analysis. Appl Radiat Isot 82: 145151.

13. Zaichick V, Zaichick S (2013) INAA application in the assessment of Ag, $\mathrm{Co}, \mathrm{Cr}, \mathrm{Fe}, \mathrm{Hg}, \mathrm{Rb}, \mathrm{Sb}, \mathrm{Sc}, \mathrm{Se}$, and $\mathrm{Zn}$ mass fraction in pediatric and young adult prostate glands. J Radioanal Nucl Chem 298(3): 1559-1566.

14. Zaichick V, Zaichick S (2013) NAA-SLR and ICP-AES Application in the assessment of mass fraction of 19 chemical elements in pediatric and young adult prostate glands. Biol Trace Elem Res 156(1-3): 357-366.

15. Zaichick V, Zaichick S (2013) Use of neutron activation analysis and inductively coupled plasma mass spectrometry for the determination of trace elements in pediatric and young adult prostate. Am J Analyt Chem 4(12): 696-706.

16. Zaichick V, Zaichick S (2014) INAA application in the assessment of chemical element mass fractions in adult and geriatric prostate glands. Appl Radiat Isot 90: 62-73.
17. Zaichick V, Zaichick S (2014) Use of INAA and ICP-MS for the assessment of trace element mass fractions in adult and geriatric prostate. J Radioanal Nucl Chem 301(2): 383-397.

18. Zaichick V, Zaichick S (2014) Determination of trace elements in adults and geriatric prostate combining neutron activation with inductively coupled plasma atomic emission spectrometry. Open Journal of Biochemistry 1(2):16-33.

19. Zaichick V, Zaichick S (2014) Age-related histological and zinc content changes in adult nonhyperplastic prostate glands. Age 36(1):167-181.

20.Zaichick V, Zaichick S (2014) Relations of bromine, iron, rubidium, strontium, and zinc content to morphometric parameters in pediatric and nonhyperplastic young adult prostate glands. Biol Trace Elem Res 157(3): 195-204.

21. Zaichick V, Zaichick S (2014) Relations of the neutron activation analysis data to morphometric parameters in pediatric and nonhyperplastic young adult prostate glands. Advances in Biomedical Science and Engineering 1(1): 26-42.

22. Zaichick V, Zaichick S (2014) Relations of the $\mathrm{Al}, \mathrm{B}, \mathrm{Ba}, \mathrm{Br}, \mathrm{Ca}, \mathrm{Cl}, \mathrm{Cu}$, $\mathrm{Fe}, \mathrm{K}, \mathrm{Li}, \mathrm{Mg}, \mathrm{Mn}, \mathrm{Na}, \mathrm{P}, \mathrm{S}, \mathrm{Si}, \mathrm{Sr}$, and $\mathrm{Zn}$ mass fractions to morphometric parameters in pediatric and nonhyperplastic young adult prostate glands. BioMetals 27(2): 333-348.

23.Zaichick V, Zaichick S (2014) The distribution of 54 trace elements including zinc in pediatric and nonhyperplastic young adult prostate gland tissues. Journal of Clinical and Laboratory Investigation Updates 2(1) :1-15.

24. Zaichick V, Zaichick S (2014) Androgen-dependent chemical elements of prostate gland. Andrology and Gynecology: Current Research 2:2.

25.Zaichick V, Zaichick S (2015) Differences and relationships between morphometric parameters and zinc content in nonhyperplastic and hyperplastic prostate glands. Br J Med Med Res 8(8): 692-706.

26. Zaichick V (2015) The variation with age of 67 macro- and microelement contents in nonhyperplastic prostate glands of adult and elderly males investigated by nuclear analytical and related methods. Biol Trace Elem Res 168(1): 44-60.

27. Zaichick V, Zaichick S (2016) Variations in concentration and distribution of several androgen-dependent and -independent trace elements in nonhyperplastic prostate gland tissue throughout adulthood. Journal of Andrology and Gynaecology 4(1): 1-10.

28. Zaichick V, Zaichick S (2016) Age-related changes in concentration and histological distribution of $\mathrm{Br}, \mathrm{Ca}, \mathrm{Cl}, \mathrm{K}, \mathrm{Mg}, \mathrm{Mn}$, and $\mathrm{Na}$ in nonhyperplastic prostate of adults. European Journal of Biology and Medical Science Research 4(2): 31-48.

29. Zaichick V, Zaichick S (2016) Age-related changes in concentration and histological distribution of 18 chemical elements in nonhyperplastic prostate of adults. World Journal of Pharmaceutical and Medical Research 2(4): 5-18.

30.Zaichick V, Zaichick S (2016) Age-related changes in concentration and histological distribution of 54 trace elements in nonhyperplastic prostate of adults. International Archives of Urology and Complications 2(2): 19.

31. Zaichick V, Sviridova T, Zaichick S (1997) Zinc in the human prostate gland: normal, hyperplastic and cancerous. Int Urol Nephrol 29(5): 565574 .

32.Zaichick S, Zaichick V (2012) Trace elements of normal, benign hypertrophic and cancerous tissues of the human prostate gland investigated by neutron activation analysis. Appl Radiat Isot 70(1): 8187.

33. Zaichick V, Zaichick S (2017) Trace element levels in prostate gland as carcinoma's marker. Journal of Cancer Therapy 8: 131-145.

34.Zaichick V, Zaichick S (2016) Ratios of selected chemical element contents in prostatic tissue as markers of malignancy. Hematology and Medical Oncology 1(2): 1-8. 
35. Zaichick V, Zaichick S (2017) Ratios of Zn/trace element contents in prostate gland as carcinoma's markers. Cancer Reports and Reviews 1(1): $1-7$

36. Zaichick V, Zaichick S (2017) Ratios of selenium/trace element contents in prostate gland as carcinoma's markers. Journal of Tumor Medicine and Prevention 1(2): 30.

37. Zaichick V, Zaichick S (2017) Ratios of rubidium/trace element contents in prostate gland as carcinoma's markers. Cancer Research and Clinical Oncology 1(1): 13-21.

38. Zaichick V, Zaichick S (2017) Ratios of cadmium/trace element contents in prostate gland as carcinoma's markers. Cancer Therapy and Oncology International Journal 4(1): 1-11.

39. Zaichick V, Zaichick S (2017) Ratios of cobalt/trace element contents in prostate gland as carcinoma's markers. The International Journal of Cancer Epidemiology and Research 1(1): 21-27.

40. Zaichick V, Zaichick S (2017) Ratios of calcium/trace elements as prostate cancer markers. Journal of Oncology Research and Therapy 4: 116.

41. Zaichick V, Zaichick S (2017) Ratios of Mg/trace element contents in prostate gland as carcinoma's markers. SAJ Cancer Science 2(1): 102.

42. Zaichick V, Zaichick S (2015) Global contamination from uranium: insights into problem based on the uranium content in the human prostate gland. Journal of Environment and Health Science 1(4): 1-5.

43. Zaichick V, Zaichick S (2015) Dietary intake of minerals and prostate cancer: insights into problem based on the chemical element contents in the prostate gland. Journal of Aging Research and Clinical Practice 4(3): 164-171.

44. Zaichick V, Zaichick S, Rossmann M (2016) Intracellular calcium excess as one of the main factors in the etiology of prostate cancer. AIMS Molecular Science 3(4): 635-647.

45. Zaichick V, Zaichick S, Wynchank S (2016) Intracellular zinc excess as one of the main factors in the etiology of prostate cancer. Journal of Analytical Oncology 5(3): 124-131.

46. Zaichick V (2014) The prostatic urethra as a Venturi effect urine-jet pump to drain prostatic fluid. Med Hypotheses 83(1): 65-68.

47. Mackenzie AR, Hall T, Whitmore WFJr (1962) Zinc content of expressed human prostate fluid. Nature (London) 193(4810): 72-73.

48. Marmar JL, Katz S, Praiss DE, DeBenedictis TJ (1980) Values for zinc in whole semen, fraction of split ejaculate and expressed prostatic fluid. Urology 16(5): 478-480.

49. Zaichick V, Tsyb A, Dunchik VN, Sviridova TV (1981) Method for diagnostics of prostate diseases. Certificate of invention No 997281 (30.03.1981) Russia.

50. Zaichick V, Sviridova T, Zaichick S (1996) Zinc concentration in human prostatic fluid: normal, chronic prostatitis, adenoma, and cancer. Int Urol Nephrol 28(5): 687-694.

51. Costello LC, Franklin RB (2009) Prostatic fluid electrolyte composition for the screening of prostate cancer: a potential solution to a major problem. Prostate Cancer Prostate Dis 12(1): 17-24.

52. Zaichick V, Zaichick S, Davydov G (2016) Method and portable facility for measurement of trace element concentration in prostate fluid samples using radionuclide-induced energy-dispersive X-ray fluorescent analysis. Nucl Sci Tech 27(6): 1-8.

53. Zaichick V, Zaichick S (2018) Effect of age on the Br, Fe, Rb, Sr, and $\mathrm{Zn}$ concentrations in human prostatic fluid investigated by energydispersive X-ray fluorescent microanalysis. MicroMed 6(2): 94-104.

54. Zaichick V, Zaichick S (2018) Br, Fe, Rb, Sr, and Zn levels in the prostatic secretion of patients with chronic prostatitis. International Archives of Urology and Complications 4: 046.
55. Zaichick V, Zaichick S (2018) Trace element concentrations in the expressed prostatic secretion of normal and hyperplastic prostate. Journal of Urology and Nephrology Studies 1(3): 1-7.

56.Zaichick V, Zaichick S (2018) Trace elements of expressed prostatic secretions as a source for biomarkers of prostatic cancer. Journal of Clinical Research in Oncology 1(1): 1-7.

57. Zaichick V, Zaichick S (2019) Ratio of zinc to bromine, iron, rubidium, and strontium concentration in the prostatic fluid of patients with benign prostatic hyperplasia. Acta Scientific Medical Sciences 3(6): 4956.

58. Zaichick V, Zaichick S (2019) Significance of trace element quantities in the prostatic secretion of patients with chronic prostatitis and prostate cancer. Journal of Biomedical Research and Reviews 2(1): 56-61.

59. Zaichick V, Zaichick S (2019) Ratio of zinc to bromine, iron, rubidium, and strontium concentration in expressed prostatic secretions as a source for biomarkers of prostatic cancer. American Journal of Research 5(6): 140-150.

60. Zaichick V, Zaichick S (2019) Some trace element contents and ratios in prostatic fluids as ancillary diagnostic tools in distinguishing between the benign prostatic hyperplasia and chronic prostatitis. Archives of Urology 2(1): 12-20.

61. Zaichick V, Zaichick S (2019) Ratio of zinc to bromine, iron, rubidium, and strontium concentration in the prostatic fluid of patients with chronic prostatitis, Global Journal of Medical Research F 19(4): 9-15.

62. Zaichick V, Zaichick S (2019) Significance of trace element quantities in the prostatic secretion of patients with benign prostatic hyperplasia and prostate cancer. Journal of Cancer Metastasis and Treatment 5(48): 1-9.

63. Zaichick V, Zaichick S (2019) Some trace element contents and ratios in prostatic fluids as ancillary diagnostic tools in distinguishing between the chronic prostatitis and prostate cancer. Medical Research and Clinical Case Reports 3(1): 1-10.

64. Zaichick V, Zaichick S (2019) Some trace element contents and ratios in prostatic fluids as ancillary diagnostic tools in distinguishing between the benign prostatic hyperplasia and prostate cancer. Cancer Therapy and Oncology International Journal 14(1): 1-7.

65. Zaichick V, Zaichick S (2019) Age-dependence of some trace element concentrations and their ratios in human prostatic fluid. Journal of Aging Research and Healthcare 2(4): 11-20.

66. Zaichick V (2019) Using prostatic fluid levels of rubidium and zinc concentration multiplication in non-invasive and highly accurate screening for prostate cancer. Journal of Cancer Prevention and Current Research 10(6): 151-158.

67. Zaichick V, Zaichick S (2019) Using prostatic fluid levels of zinc to bromine concentration ratio in non-invasive and highly accurate screening for prostate cancer. Journal of Hematology and Oncology Research 3(3): 21-31.

68. Zaichick V, Zaichick S (2019) Using prostatic fluid levels of zinc to iron concentration ratio in non-invasive and highly accurate screening for prostate cancer. SSRG International Journal of Medical Science 6(11): 24-31.

69. Zaichick V, Zaichick S (2020) Using prostatic fluid levels of zinc to strontium concentration ratio in non-invasive and highly accurate screening for prostate cancer. Acta Scientific Cancer Biology 4(1): 12-21.

70. Zaichick V (2006) Medical elementology as a new scientific discipline. J Radioanal Nucl Chem 269: 303-309.

71. Birnbaum D, Hall T, Lee R (1961) Zinc content of rat sperm cells from ejaculate, vas, spididymis and testis. Pros Soc Exper Biol Med 108(2): 321-324.

72. Burgos MH ((1974) Biochemical and functional properties related to sperm metabolism and fertility". In: Brandes D (Editor) Male accessory sex organs, Academic press, New York. pp.151-160. 
73. Marmar JL, Katz S, Praiss DE, DeBenedictis TJ (1975) Semen zinc levels in infertile and post vasectomy patients and partients with prostatitis". Fertility and Sterility 26(11): 1057-1063.

74. Anderson RU, Fair WR (1976) Physical and chemical determinations of prostatic secretion in benign hyperplasia, prostatitis, and adenocarcinoma. Invest Urol 14(2): 137-140.

75. Fair WR, Couch J, Wehner N (1976) Prostatic antibacterial factor. Identity and significance. Urology 7(2): 169-177.

76. Paz G, Sofer A, Homonnai ZT, Kraicer PF (1977) Human semen analysis. Seminal plasma and prostatic fluid composition and their interrelations with sperm quality. Int J Fertil 22(3): 140-147.

77. Fair WR, Cordonnier JJ (1978) The $\mathrm{pH}$ of prostatic fluid: A reappraisal and therapeutic implications. J Urol 120(6): 695-698.

78. Homonnai ZT, Matzkin H, Fainman N, Paz G, Kraicer PF (1978) The cation composition of the seminal plasma and prostatic fluid and its correlation to semen quality. Fertil Steril 29(5): 539-542.

79. Zaneveld LJD, Tauber PF (1981) Contribution of prostatic fluid components to the ejaculate. In: Murphy GP, et al. Prostatic Cell: Structure and Function, Alan R. Liss, New York. pp. 265-277.

80. Kavanagh JP, Darby C (1982) The interrelationships between acid phosphatase, aminopeptidase, diamine oxidase, citric acid, $\beta$-glucuronidase, $\mathrm{pH}$ and zinc in human prostate fluid. Int J Androl 5(5): 503-512.

81. Kavanagh JP (1983) Zinc binding properties of human prostatic tissue, prostatic secretion and seminal fluid. J Reprod Fert 68(2): 359-363.

82. Mo ZN, Huang WH, Chen J, Huang X, Zhang SC (2000) Early and late longterm effects of vasectomy on $\mathrm{Zn}, \mathrm{Cd}$, and Cu levels in prostatic fluid and serum. Asian J Androl 2(2): 121-124.
83. Cui D, Han G, Shang Y, Mu L, Long Q Du Y (2015) The effect of chronic prostatitis on zinc concentration of prostatic fluid and seminal plasma: a systematic review and meta-analysis. Curr Med Res Opin 31(9): 17631769.

84. Gomes Y, Arocha F, Espinoza F, Fernandez D, Vasquez A, et al (2007) Zinc levels in prostatic fluid of patients with prostate pathologies. Invest Clin 48(3): 287-294.

85.Zaichick V (1997) Sampling, sample storage and preparation of biomaterials for INAA in clinical medicine, occupational and environmental health. In: Harmonization of Health-Related Environmental Measurements Using Nuclear and Isotopic Techniques. International Atomic Energy Agency, Vienna. pp. 123-133.

86. Zaichick V, Zaichick S (1997) A search for losses of chemical elements during freeze-drying of biological materials. J Radioanal Nucl Chem 218(2): 249-253

87. Zaichick V (2004) Losses of chemical elements in biological samples under the dry aching process. Trace Elements in Medicine 5(3): 17-22.

88. Rossmann M, Zaichick S, Zaichick V (2016) Determination of key chemical elements by energy dispersive X-Ray fluorescence analysis in commercially available infant and toddler formulas consumed in UK. Nutr Food Technol Open Access 2(4): 1-7.

89. Iyengar GV, Kollmer WE, Bowen HGM (1978) The elemental composition of human tissues and body fluids. A compilation of values for adults. Verlag Chemie, Weinheim, Germany. pp. 151.

90. Iyengar GV (1998) Reevaluation of the trace element content in reference men. Radiat Phys Chem 51(4-6): 545-560.

91. Zaichick V, Tsyb A, Bagirov S (1995) Neutron activation analysis of saliva: clinical chemistry, environmental and occupational toxicology. J Radioanal Nucl Chem 195(1): 123-132. 